\title{
Changes in Cell Viability of Wounded Fibroblasts following Laser Irradiation in Broad-Spectrum or Infrared Light
}

\author{
Denise Hawkins and Heidi Abrahamse \\ Laser Research Group, Faculty of Health, University of Johannesburg, P.O. Box 17011, Doornfontein 2028, Johannesburg, South Africa
}

Received 29 June 2006; Revised 14 August 2006; Accepted 22 August 2006

Recommended by Frederik Claeyssens

Objective. This study aimed to establish if broad-spectrum or infrared (IR) light in combination with laser therapy can assist phototherapy to improve the cell function of wounded cells. Background. The effect of laser light may be partly or completely reduced by broad-spectrum light. Methods. Wounded human skin fibroblasts were irradiated with $5 \mathrm{~J} / \mathrm{cm}^{2}$ using a helium-neon laser, a diode laser, or an Nd:YAG laser in the dark, in the light, or in IR. Changes in cell viability were evaluated by cell morphology, ATP cell viability, LDH membrane integrity, and caspase $3 / 7$ as an early marker of apoptosis. Results. Wounded cells exposed to $5 \mathrm{~J} / \mathrm{cm}^{2}$ using $632.8 \mathrm{~nm}$ in the dark or $830 \mathrm{~nm}$ in the light or $1064 \mathrm{~nm}$ in the dark showed an increase in ATP viability, an increase in cytokine expression, and a decrease in LDH cytotoxicity indicating that the metabolic activity of the wounded cells was stimulated. Conclusion. Wounded cells irradiated in IR light showed an undesirable thermal effect that was proportional to the duration of exposure.

Copyright (C) 2007 D. Hawkins and H. Abrahamse. This is an open access article distributed under the Creative Commons Attribution License, which permits unrestricted use, distribution, and reproduction in any medium, provided the original work is properly cited.

\section{INTRODUCTION}

Light is considered part of the spectrum of electromagnetic energy. This spectrum includes wavelengths of energy that vary considerably in length from the very short waves in the ultraviolet end of the spectrum (gamma and X-rays) to the very long waves at the infrared extreme of the spectrum [1]. In the visible portion of the spectrum, light is composed of wavelengths that range from $400 \mathrm{~nm}$ to $800 \mathrm{~nm}$. Tissue is generally more transparent to near-IR wavelengths (800$1200 \mathrm{~nm}$ ) than to visible light [1].

\section{Properties of laser light}

(i) Laser light is collimated, meaning that the beam travels in a single direction without divergence over a long distance with a high intensity. Ordinary light scatters rather quickly and does not provide illumination over any real distance [1].

(ii) Laser light is monochromatic, with all waves having the same wavelength or frequency. By generating light of one specific wavelength, lasers can be more specific in their application. In medical lasers, the laser effect is dependent upon targeted tissue's inherent sensitivity to a particular wavelength. Ordinary light is composed of many different wavelengths or colors [1].

(iii) Laser light is coherent, with all waves in phase. The peaks and troughs of each wave are synchronous in space. Normal light is composed of light traveling in many different directions and out of phase [1].

A laser, whether large or small, always includes the following parts: an energy source (power supply), a lasing or amplifying medium (solid, liquid, or gas), and a resonating cavity (mirrors). Neodynium:yttrium-aluminumgarnet (Nd:YAG) lasers have short wavelengths (1064 nm and $1440 \mathrm{~nm}$ ) within the infrared (invisible) zone of the spectrum. Neodynium's wavelength is relatively poorly absorbed by water (and thus most relevant to musculoskeletal tissues), and it therefore penetrates tissue for relatively greaterthan-desired depths, estimated at $4-6 \mathrm{~mm}$ in a vascular tissue $[1,2]$. When less is absorbed by target tissue, more laser energy is transmitted beyond the target. This unintended effect can lead to inadvertent heating of deeper tissues and clinically significant thermal damage. Reports of thermal necrosis caused by subchondral bone penetration soon followed the clinical introduction of the Nd:YAG laser and signified its rapid efficiency demise $[1,2]$. 
Semiconductor lasers are small, potentially inexpensive, and much more efficient than traditional lasers. Diode lasers generate low powers generally below $1.0 \mathrm{~W}$. The diode laser is an example of a semiconductor laser used in ophthalmology for photocoagulation. Fibers easily transmit diode laser radiation, which can be pulsed or continuous [2].

The helium-neon ( $\mathrm{HeNe}$ ) laser emits red laser light at a wavelength of $632.8 \mathrm{~nm}$ and is within the visible spectrum. HeNe lasers only operate in continuous-wave (CW) mode and no cooling system is required. The maximum power output $(50-60 \mathrm{~mW})$ is so weak that these are not useful as surgical lasers $[2,3]$. The laser can be used as a visible guide beam that accompanies otherwise invisible treating laser beams. HeNe laser light can penetrate as far as 0.5$50 \mathrm{~mm}$ into freshly excised human skin and delivers the highest relative percentage of incident energy to a certain volume of tissue. A penetration depth of even some microns can be regarded as sufficient, because most of the relevant target cells of low-level laser irradiation, namely fibroblasts, keratinocytes, macrophages, and endothelial cells for the induction of wound healing, are located within the epidermis and upper dermis [4]. The HeNe laser has been reported to stimulate wound healing and cell growth [4] and is frequently used for biostimulation in pain management and for wound healing [2].

Cell cultures that are first irradiated with laser light and have consequently exhibited biological effects which are then irradiated with broad-spectrum (nonmonochromatic and incoherent) light, subsequently have their laser-produced biological effects reduced to almost nothing [5]. Karu et al. [5] demonstrated stimulating biological effects in cell cultures from monochromatic incoherent light and indicated that there are more mechanisms at work than simply the excitation of polarization-sensitive chromophores [5]. The influence of ambient light may influence the outcome of both clinical and laboratory studies [5] and may well explain some of the variability in the results/effects reported in the literature.

Experiments following phototherapy have shown that immediate heat rise in target tissue is negligible $\left( \pm 1^{\circ} \mathrm{C}\right)$. Stadler et al. [6] used a mouse model to demonstrate that black skin $\left(4.5 \pm 0.15^{\circ} \mathrm{C}\right)$ exhibits a greater temperature change relative to white skin $\left(0.3 \pm 0.10^{\circ} \mathrm{C}\right)$, thus failure to consider this variable can result in thermal damage and unwanted thermal influences during phototherapy [6]. Greppi [7] investigated the use of an $810 \mathrm{~nm}$ wavelength diode laser for hair removal using low-energy settings and long pulse duration and concluded that diode lasers can be used on dark pigmented skin with positive outcomes [7]. Complications such as hypopigmentation, or hyperpigmentation do occur, but all are temporary and resolve within a few months. The $810 \mathrm{~nm}$ wavelength diode laser can safely and successfully treat all skin types, including dark pigmented skin [7]. Visible and infrared irradiations has a pronounced wound healing effect, which develops as a consequence of local and systemic light effects, but many aspects of their mechanism are still unclear [8].
Kubota [9] investigated the effect of defocused galliumaluminium-arsenide (GaAlAs) diode laser therapy $(830 \mathrm{~nm}$, $\mathrm{CW}, 669 \mathrm{~mW} / \mathrm{cm}^{2}, 6.3 \mathrm{~J} / \mathrm{cm}^{2}$ to $\left.21 \mathrm{~J} / \mathrm{cm}^{2}\right)$ in the treatment of unresponsive skin ulcers and reported that $830 \mathrm{~nm}$ diode laser therapy was well tolerated, and was very effective in the treatment of compromised skin ulcers of different etiologies in a large range of patient ages [9]. Meffert et al. [10] studied the systemic effect of ultraviolet, visible, and infrared radiation in whole body irradiation using experimental conditions similar to those used in phototherapeutical practice [10]. The study concluded that there were no negative side effects after the application of large doses of visible or infrared radiation and considerable systemic responses were exclusively found with ultraviolet irradiation [10]. Belotsky et al. [11] studied the effect of visible-light irradiation of $5 \mathrm{~J} / \mathrm{cm}^{2}$ and $12 \mathrm{~J} / \mathrm{cm}^{2}$ applied to buffy coat leukocytes [11]. The study found an inhibitory effect dependent on the light intensity that was more pronounced at $12 \mathrm{~J} / \mathrm{cm}^{2}$.

Little information is available regarding the potential thermal effects of near-infrared photoradiation during lowlevel laser therapy (LLLT) [12]. Lanzafame et al. [12] studied the effect of temperature-controlled $830 \mathrm{~nm}$ LLLT on experimental pressure ulcers created in C57BL mice and reported that the group receiving laser therapy $(830 \mathrm{~nm}$ $5 \mathrm{~J} / \mathrm{cm}^{2}, \mathrm{CW}$ ) showed a maximum temperature change during therapy of $2.0 \pm 0.64^{\circ} \mathrm{C}$ and complete wound closure at $18 \pm 4$ days while the group receiving incandescent light $\left(5 \mathrm{~J} / \mathrm{cm}^{2}\right)$ showed a maximum temperature change during therapy of $3.54 \pm 0.72^{\circ} \mathrm{C}$ and complete wound closure at $25 \pm 6$ days [12]. The results also showed that the group receiving incandescent light had a $36.3 \pm 4.8 \%$ wound closure at day 14 while the group receiving laser therapy showed a significantly higher rate of wound closure at $75.4 \pm 7.2 \%$ [12].

Maegawa et al. [13] studied the relationship between temperature increase and enhanced microcirculation during near-infrared irradiation and found a $0.8-1.0^{\circ} \mathrm{C}$ increase in temperature and enhanced microcirculation in exteriorized rat mesentery during irradiation at $830 \mathrm{~nm}$ with a $38 \mathrm{~mW}$ power output [13].

There are few studies that investigate the benefit or detriment of combining laser irradiation with broad-spectrum (visible white light) or infrared light (ExoTerra Heat Glo, $240 \mathrm{~V}, 100 \mathrm{~W})$. This study aimed to establish if broadspectrum or infrared light has any benefit when irradiating wounded human skin fibroblast with a dose of $5 \mathrm{~J} / \mathrm{cm}^{2}$ using an $\mathrm{HeNe}(632.8 \mathrm{~nm}, 18.8 \mathrm{~mW})$ laser, a diode $(830 \mathrm{~nm}$, $65 \mathrm{~mW}$ ) laser, or an Nd:YAG (1064 nm, 1 W). Wounded cells irradiated in IR light demonstrate an undesirable thermal effect that is proportional to the duration or length of exposure. Wounded cells responded with an increase in cell function and viability when exposed to $5 \mathrm{~J} / \mathrm{cm}^{2}$ using $632.8 \mathrm{~nm}$ in the dark, $830 \mathrm{~nm}$ in the light, or $1064 \mathrm{~nm}$ in the dark. Results indicate that $5 \mathrm{~J} / \mathrm{cm}^{2}$ using $632.8 \mathrm{~nm}$ in the dark or $830 \mathrm{~nm}$ in the light are the most effective doses, which may ultimately stimulate wounded cells to accelerate or improve the rate of wound healing. 


\section{MATERIALS AND METHODS}

\subsection{Cell culture procedure}

Human skin fibroblast monolayer cultures (ATCC CRL1502 WS1) were grown in Eagle's minimal essential medium with Earle's balanced salt solution that was modified to contain $2 \mathrm{mM}$ L-glutamine, $1.0 \mathrm{mM}$ sodium pyruvate, $0.1 \mathrm{mM}$ nonessential amino acids, $1 \%$ fungizone, and $1 \%$ penicillinstreptomycin and supplemented with $10 \% \mathrm{~V} / \mathrm{V}$ foetal bovine serum (serum rich medium). The cultures were incubated at $37^{\circ} \mathrm{C}$ with $5 \% \mathrm{CO}_{2}$ and $85 \%$ humidity [14]. Cells were trypsinized using a $0.25 \%(\mathrm{w} / \mathrm{v})$ trypsin- $0.03 \%$ EDTA solution in Hanks balanced salt solution (HBSS) and approximately $6.5 \times 10^{5}$ cells (in $3 \mathrm{~mL}$ culture medium) were seeded in $3.4 \mathrm{~cm}$ diameter culture plates and incubated overnight to allow the cells to attach [15].

\subsection{Laser specifications and exposure regime}

Once the fibroblasts had attached, $2 \mathrm{~mL}$ of culture medium was removed and a wound was induced before the cells were irradiated. Normal and wounded fibroblasts were exposed to $5 \mathrm{~J} / \mathrm{cm}^{2}$ on day 1 and day 4 . Since the HeNe laser has a power density between $2.07 \mathrm{~mW} / \mathrm{cm}^{2}$ and a spot size of $3.4 \mathrm{~cm}$, the light is divergent and is not as harmful as a narrow parallel beam that allows the entire volume of intense light to be focused, or concentrated on one small area [16]. For the simulated wound environment, confluent monolayers were first scratched with a sterile pipette of $2 \mathrm{~mm}$ diameter and the plates were incubated at $37^{\circ} \mathrm{C}$ for 30 minutes before they were irradiated [17-19]. Each scratch was irregular and the size of the wounds ranged from 1 to $2 \mathrm{~mm}$ in diameter [1719].

Wounded cells were exposed to $5 \mathrm{~J} / \mathrm{cm}^{2}$ either in the dark or in broad-spectrum white light or in infrared light (Exo Terra Heat Glo, 240 V, $100 \mathrm{~W}, 17.5 \mathrm{~cm}$ above cells). Irradiations were performed with an HeNe laser $(632.8 \mathrm{~nm}$, $18.8 \mathrm{~mW}$ power output, $2.07 \mathrm{~mW} / \mathrm{cm}^{2}$ power density, and $3.4 \mathrm{~cm}$ diameter spot size or area $9.1 \mathrm{~cm}^{2}$ ), a semiconductor diode laser $\left(830 \mathrm{~nm}, 54 \mathrm{~mW}\right.$ power output, $5.95 \mathrm{~mW} / \mathrm{cm}^{2}$ power density, and $3.4 \mathrm{~cm}$ diameter spot size or area $\left.9.1 \mathrm{~cm}^{2}\right)$, and an Nd:YAG laser $(1064 \mathrm{~nm}, 1 \mathrm{~W}$ power output, $12.73 \mathrm{~mW} / \mathrm{cm}^{2}$ power density, and $10 \mathrm{~cm}$ diameter spot size (to accommodate four culture dishes simultaneously) or area $78.5 \mathrm{~cm}^{2}$ ) using the following exposures:

(i) wounded unirradiated control cells $\left(0 \mathrm{~J} / \mathrm{cm}^{2}\right)$;

(ii) wounded human skin fibroblasts exposed to $5 \mathrm{~J} / \mathrm{cm}^{2}$.

Using an average laser power density of $2.07 \mathrm{~mW} / \mathrm{cm}^{2}$, the duration of each exposure for the HeNe laser was calculated at 41 minutes and 40 seconds for $5 \mathrm{~J} / \mathrm{cm}^{2}$. Using an average laser power density of $5.95 \mathrm{~mW} / \mathrm{cm}^{2}$, the duration of each exposure for the $830 \mathrm{~nm}$ diode laser was calculated at 12 minutes and 45 seconds while using an average laser power density of $12.73 \mathrm{~mW} / \mathrm{cm}^{2}$ for the Nd:YAG, the duration of the exposure was 6 minutes and 30 seconds for $5 \mathrm{~J} / \mathrm{cm}^{2}$. The cellular response measurements (biological assays) were made 24 hours (day 5) after laser irradiation to observe the modifications or responses that occur with time [20].

\subsection{Biological assays}

Following laser irradiation, the fibroblasts were trypsinized from the $3.4 \mathrm{~cm}$ culture dishes and the cell suspension $(1 \times$ $10^{5}$ cells $/ 100 \mu \mathrm{L}$ ) was used to assess the effect of laser irradiation on cell viability using cell morphology, the ATP luminescent viability assay, and caspase 3/7 activity. The culture medium was used to assess damage or additional stress caused by the irradiation using the LDH membrane integrity assay.

\section{Changes in cell morphology}

The control (unirradiated or $0 \mathrm{~J} / \mathrm{cm}^{2}$ ) and wounded fibroblast behavior were observed using an inverted microscope. The number and intensity of colony formation, the haptotaxis (direction or orientation) of the edge fibroblasts, the number of fibroblasts present in the centre of the scratch, and chemotaxis-chemokinesis (movement or migration of cells across the central scratch) were evaluated to determine the activity of fibroblasts [21].

\section{ATP cell viability assay}

The CellTiter-Glo luminescent cell viability assay (Promega G7570) is based on the quantitation of ATP present, which signals the presence of metabolically active cells or viable cells [22]. An equal volume of reconstituted CellTiter-Glo reagent was added to $50 \mu \mathrm{L}$ of cell suspension $\left(1 \times 10^{5}\right.$ cells $\left./ 100 \mu \mathrm{L}\right)$. The contents were mixed on an orbital shaker for 2 minutes to induce cell lysis and were then incubated at room temperature for 10 minutes to stabilize the luminescent signal, which was recorded using a Berthold EG and Junior luminometer $[22,23]$.

\section{LDH membrane integrity}

The CytoTox 96 nonradioactive cytotoxicity assay (Promega G1780) measures lactate dehydrogenase (LDH), a stable cytosolic enzyme that is released upon cell lysis [24]. Five hundred $\mu \mathrm{L}$ of culture medium were removed from each plate after each irradiation. Fifty $\mu \mathrm{L}$ of the culture medium were mixed with an equal volume of reconstituted substrate mix. The plate was covered with foil and incubated at room temperature for 30 minutes. Fifty $\mu \mathrm{L}$ of stop solution were added and the absorbance was read at $490 \mathrm{~nm}$ [24].

\section{Apoptosis}

The caspase-Glo 3/7 (Promega G8090) assay is a luminescent assay that measures caspases -3 and -7 activity. Apoptosis can be induced by stress from growth factor withdrawal or irradiation and is mediated by a cascade of highly specific proteases known as caspases [25]. Caspases 3, 6, and 7 are effector caspases that cleave cellular substrates and 
precipitate apoptotic death [26]. The addition of caspase-Glo $3 / 7$ reagent results in cell lysis, followed by caspase cleavage of the substrate and generation of a luminescent signal produced by luciferase. Twenty five $\mu \mathrm{L}$ of the cell suspension $\left(1 \times 10^{5}\right.$ cells $\left./ 100 \mu \mathrm{L}\right)$ were added to $25 \mu \mathrm{L}$ of caspase-Glo $3 / 7$ reagent and the tube was mixed and incubated at room temperature for 3 hours. The luminescent signal was recorded which is directly proportional to the amount of caspase activity present [25].

\section{Statistical analysis}

Each experiment was repeated on different populations of wounded fibroblast cells between passage 13-31. Each biological assay was performed in duplicate and the average of the two results was used to obtain a final sample number of $n=4$. The results were recorded for statistical analysis using SigmaPlot 8.0 and the mean, standard deviation, standard error, and significant percentage change between the un-irradiated control $\left(0 \mathrm{~J} / \mathrm{cm}^{2}\right)$ and the irradiated cells were calculated for each data group and graphically represented. The Student $t$ test and one-way analysis of variance (ANOVA) were used to analyze the difference firstly between the un-irradiated control $\left(0 \mathrm{~J} / \mathrm{cm}^{2}\right)$ and the irradiated cells and secondly between the different data groups. Statistical significance was accepted at the 0.05 level (95\% confidence interval). The \pm value or error bars in the figures indicate standard error of the mean (SEM).

\section{RESULTS}

Fibroblast behavior was observed using an inverted microscope and changes in cell morphology were digitally recorded daily. Normal human skin fibroblasts are long slender cells that grow in monolayer sheets $-\times 40$ magnification. For the simulated wound environment, confluent monolayers were first scratched with a sterile pipette of $2 \mathrm{~mm}$ diameter and the plates were incubated at $37^{\circ} \mathrm{C}$ for 30 minutes before they were irradiated. A clear central scratch with a distinct wound margin (wm) could be observed directly after inducing a mechanical scratch [17-19]. Morphological changes that were assessed included haptotaxis (h) or change in orientation of the edge fibroblasts, chemotaxis-chemokinesis or migration (m) of cells across the central scratch, colony formation along the wound margin, and number of fibroblasts present in the central scratch (f) $-\times 10$ magnification. Wounded irradiated cells showed evidence of haptotaxis and migration of fibroblasts across the central scratch in an attempt to close the wound (Figure 1).

\section{ATP cell viability assay}

The ATP luminescent assay was used to determine the effect of laser irradiation on the viability of wounded fibroblasts. The measurements were made 24 hours post-laser irradiation (Figure 2). Wounded cells exposed to $5 \mathrm{~J} / \mathrm{cm}^{2}$ using $632.8 \mathrm{~nm}$ in the light showed a decrease in the ATP viability when compared to wounded cells exposed to $5 \mathrm{~J} / \mathrm{cm}^{2}$ in the dark $(P=0.022)$ indicating that cells irradiated with $5 \mathrm{~J} / \mathrm{cm}^{2}$ in broad-spectrum (nonmonochromatic and incoherent) light exhibit a decrease in biological response to the laser light when compared to cells irradiated with the same dose in the dark [5]. This suggests that there are more mechanisms at work than simply the excitation of polarizationsensitive chromophores [5].

Wounded cells exposed to $5 \mathrm{~J} / \mathrm{cm}^{2}$ using $632.8 \mathrm{~nm}$ in the dark, light, and IR showed a decrease in ATP viability of $-3.789 \%(P=0.587),-12.892 \%(P=0.192)$, and $-24.972 \%(P=0.078)$, respectively, when compared to the wounded unirradiated control. Wounded cells exposed to $5 \mathrm{~J} / \mathrm{cm}^{2}$ using $830 \mathrm{~nm}$ in the dark, light, and IR showed a decrease in ATP viability of $-5.341 \%(P=0.626),-2.694 \%$ $(P=0.785)$, and $-12.354 \%(P=0.417)$, respectively, when compared to the wounded unirradiated control. Wounded cells exposed to $5 \mathrm{~J} / \mathrm{cm}^{2}$ using $830 \mathrm{~nm}$ in IR showed a decrease in the ATP viability when compared to wounded cells exposed to $5 \mathrm{~J} / \mathrm{cm}^{2}$ in the light $(P=0.053)$. Wounded cells exposed to $5 \mathrm{~J} / \mathrm{cm}^{2}$ using $632.8 \mathrm{~nm}$ in the light showed a decrease in ATP viability when compared to wounded cells exposed to $5 \mathrm{~J} / \mathrm{cm}^{2}$ using $830 \mathrm{~nm}$ in the light $(P=$ 0.002 ). Wounded cells exposed to $5 \mathrm{~J} / \mathrm{cm}^{2}$ using $830 \mathrm{~nm}$ in the dark showed a decrease in ATP viability when compared to wounded cells exposed to $5 \mathrm{~J} / \mathrm{cm}^{2}$ using $632.8 \mathrm{~nm}$ in the dark $(P=0.048)$ indicating that the biological response is dependent on the wavelength. The results indicate that both the wavelength $(632.8 \mathrm{~nm}, 830 \mathrm{~nm}$, or $1064 \mathrm{~nm})$ and irradiation conditions (light, dark, or IR) contribute to different biological responses of wounded cells.

Wounded cells exposed to $5 \mathrm{~J} / \mathrm{cm}^{2}$ using $1064 \mathrm{~nm}$ in the dark, light, and IR showed a decrease in ATP viability of $-7.778 \%(P=0.801),-10.436 \%(P=0.520)$, and $-4.121 \%$ $(P=0.673)$, respectively, when compared to the wounded unirradiated control. Wounded cells exposed to $5 \mathrm{~J} / \mathrm{cm}^{2}$ using $1064 \mathrm{~nm}$ in the light showed a decrease in ATP viability when compared to wounded cells exposed to $5 \mathrm{~J} / \mathrm{cm}^{2}$ using $1064 \mathrm{~nm}$ in IR $(P=0.071)$. Wounded cells exposed to $5 \mathrm{~J} / \mathrm{cm}^{2}$ using $1064 \mathrm{~nm}$ in the dark showed a decrease in ATP viability when compared to wounded cells exposed to $5 \mathrm{~J} / \mathrm{cm}^{2}$ using $1064 \mathrm{~nm}$ in IR $(P=0.128)$.

Wounded cells exposed to $5 \mathrm{~J} / \mathrm{cm}^{2}$ using $1064 \mathrm{~nm}$ in the light showed a decrease in ATP viability when compared to wounded cells exposed to $5 \mathrm{~J} / \mathrm{cm}^{2}$ using $830 \mathrm{~nm}$ in the light $(P=0.050)$. Wounded cells exposed to $5 \mathrm{~J} / \mathrm{cm}^{2}$ using $830 \mathrm{~nm}$ in IR showed a decrease in ATP viability when compared to wounded cells exposed to $5 \mathrm{~J} / \mathrm{cm}^{2}$ using $1064 \mathrm{~nm}$ in $\operatorname{IR}(P=0.074)$. Wounded cells exposed to $5 \mathrm{~J} / \mathrm{cm}^{2}$ using $632.8 \mathrm{~nm}$ in IR showed a decrease in ATP viability when compared to wounded cells exposed to $5 \mathrm{~J} / \mathrm{cm}^{2}$ using $1064 \mathrm{~nm}$ in IR $(P=0.018)$.

\section{LDH membrane integrity assay}

Changes in cell membrane integrity were measured using $\mathrm{LDH}$ membrane integrity assay since $\mathrm{LDH}$ is a stable cytosolic enzyme that is released upon membrane damage [24]. Wounded cells exposed to $5 \mathrm{~J} / \mathrm{cm}^{2}$ using $632.8 \mathrm{~nm}$ in IR 


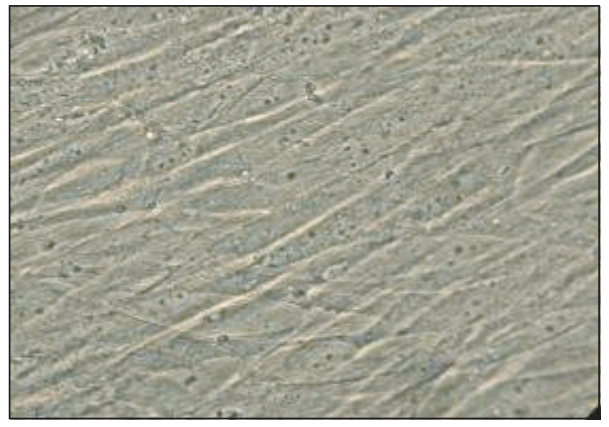

(a)

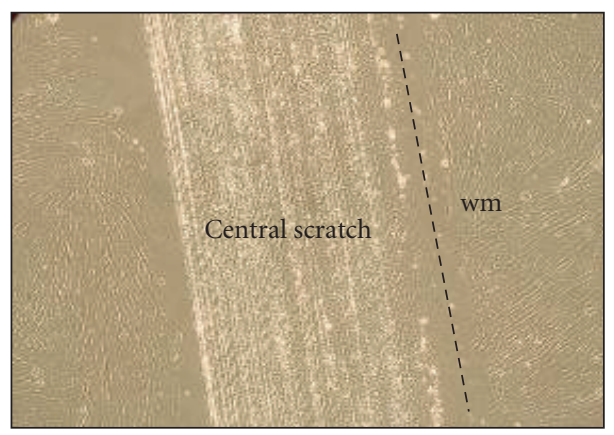

(c)

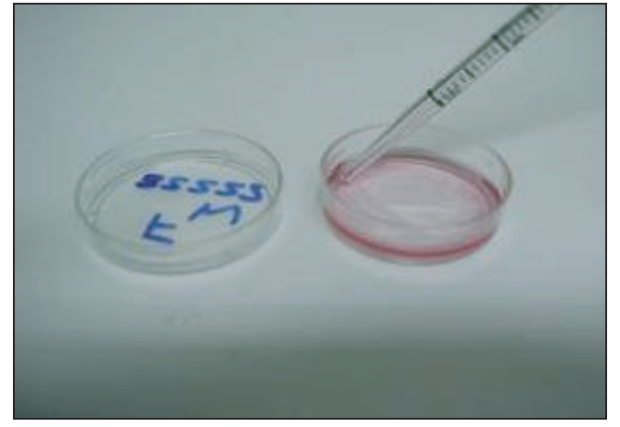

(b)

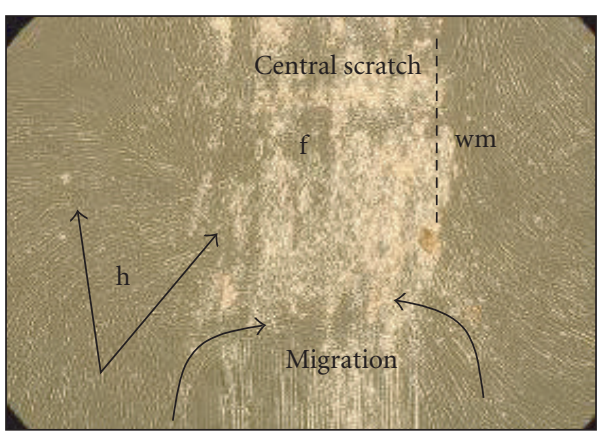

(d)

FIGURE 1: Fibroblast behavior was observed using an inverted microscope and changes in cell morphology were digitally recorded daily. Normal human skin fibroblasts are long slender cells that grow in monolayer sheets $-\times 40$ magnification (a). For the simulated wound environment, confluent monolayers were first scratched with a sterile pipette of $2 \mathrm{~mm}$ diameter and the plates were incubated at $37^{\circ} \mathrm{C}$ for 30 minutes before they were irradiated (b). A clear central scratch with a distinct wound margin (wm) could be observed directly after inducing a mechanical scratch (c). Morphological changes that were assessed included haptotaxis (h) or change in orientation of the edge fibroblasts, chemotaxis-chemokinesis or migration $(\mathrm{m})$ of cells across the central scratch, colony formation along the wound margin (wm), and number of fibroblasts (f) present in the central scratch $-\times 10$ magnification $(d)$.

showed an increase in cytotoxicity when compared to the unirradiated control $(P=0.010)$ and when compared to wounded cells exposed to $5 \mathrm{~J} / \mathrm{cm}^{2}$ using $632.8 \mathrm{~nm}$ in the dark $(P=0.950)$ and in the light $(P=0.476)$. The result supports the ATP viability, which suggests that cells irradiated in broad-spectrum light exhibit a decrease in biological response (Figure 2).

Wounded cells exposed to $5 \mathrm{~J} / \mathrm{cm}^{2}$ using $830 \mathrm{~nm}$ in IR showed an increase in cytotoxicity when compared to wounded cells exposed to $5 \mathrm{~J} / \mathrm{cm}^{2}$ using $830 \mathrm{~nm}$ in the dark $(P=0.001)$ and in the light $(P=0.0003)$. The result corresponds to the ATP viability result, which suggests that cells irradiated in IR light exhibit a decrease in biological response. Wounded cells exposed to $5 \mathrm{~J} / \mathrm{cm}^{2}$ using $632.8 \mathrm{~nm}$ in IR showed an increase in cytotoxicity when compared to wounded cells exposed to $5 \mathrm{~J} / \mathrm{cm}^{2}$ using $830 \mathrm{~nm}$ in IR $(P=0.082)$ indicating that the extended irradiation time results in an undesirable thermal effect that causes an increase in cytotoxicity and decrease in cell viability. The result show that there is a statistical difference between cells irradiated with $632.8 \mathrm{~nm}$ and $830 \mathrm{~nm}$ in IR indicating that either the wavelength or that the irradiation time influences the total cellular response.
Wounded cells exposed to $5 \mathrm{~J} / \mathrm{cm}^{2}$ using $1064 \mathrm{~nm}$ in IR showed an increase in cytotoxicity when compared to wounded cells exposed to $5 \mathrm{~J} / \mathrm{cm}^{2}$ using $1064 \mathrm{~nm}$ in the dark $(P=0.008)$ and in the light $(P=0.587)$. The results indicate that wounded cells exposed to $5 \mathrm{~J} / \mathrm{cm}^{2}$ using $1064 \mathrm{~nm}$ in the light show an increase in cytotoxicity when compared to wounded cells exposed to $5 \mathrm{~J} / \mathrm{cm}^{2}$ using $1064 \mathrm{~nm}$ in the dark $(P=0.0004)$ and which corresponds to a decrease in ATP cell viability. Wounded cells exposed to $5 \mathrm{~J} / \mathrm{cm}^{2}$ using $1064 \mathrm{~nm}$ in the dark showed a decrease in cytotoxicity when compared to the unirradiated $(P=0.174)$ and when compared to wounded cells exposed to $5 \mathrm{~J} / \mathrm{cm}^{2}$ using $830 \mathrm{~nm}$ in the dark $(P=0.0003)$. Wounded cells exposed to $5 \mathrm{~J} / \mathrm{cm}^{2}$ using $1064 \mathrm{~nm}$ in the dark showed a decrease in cytotoxicity when compared to wounded cells exposed to $5 \mathrm{~J} / \mathrm{cm}^{2}$ using $632.8 \mathrm{~nm}$ in the dark $(P=0.109)$. Wounded cells exposed to $5 \mathrm{~J} / \mathrm{cm}^{2}$ using $830 \mathrm{~nm}$ in IR showed an increase in cytotoxicity when compared to wounded cells exposed to $5 \mathrm{~J} / \mathrm{cm}^{2}$ using $1064 \mathrm{~nm}$ in IR $(P=0.063)$.

There was no statistical difference between wounded cells exposed to $5 \mathrm{~J} / \mathrm{cm}^{2}$ using $632.8 \mathrm{~nm}$ and $830 \mathrm{~nm}$ in the light $(P=0.141)$ and between wounded cells exposed to $5 \mathrm{~J} / \mathrm{cm}^{2}$ using $1064 \mathrm{~nm}$ and $632.8 \mathrm{~nm}$ in the light $(P=0.975)$, 


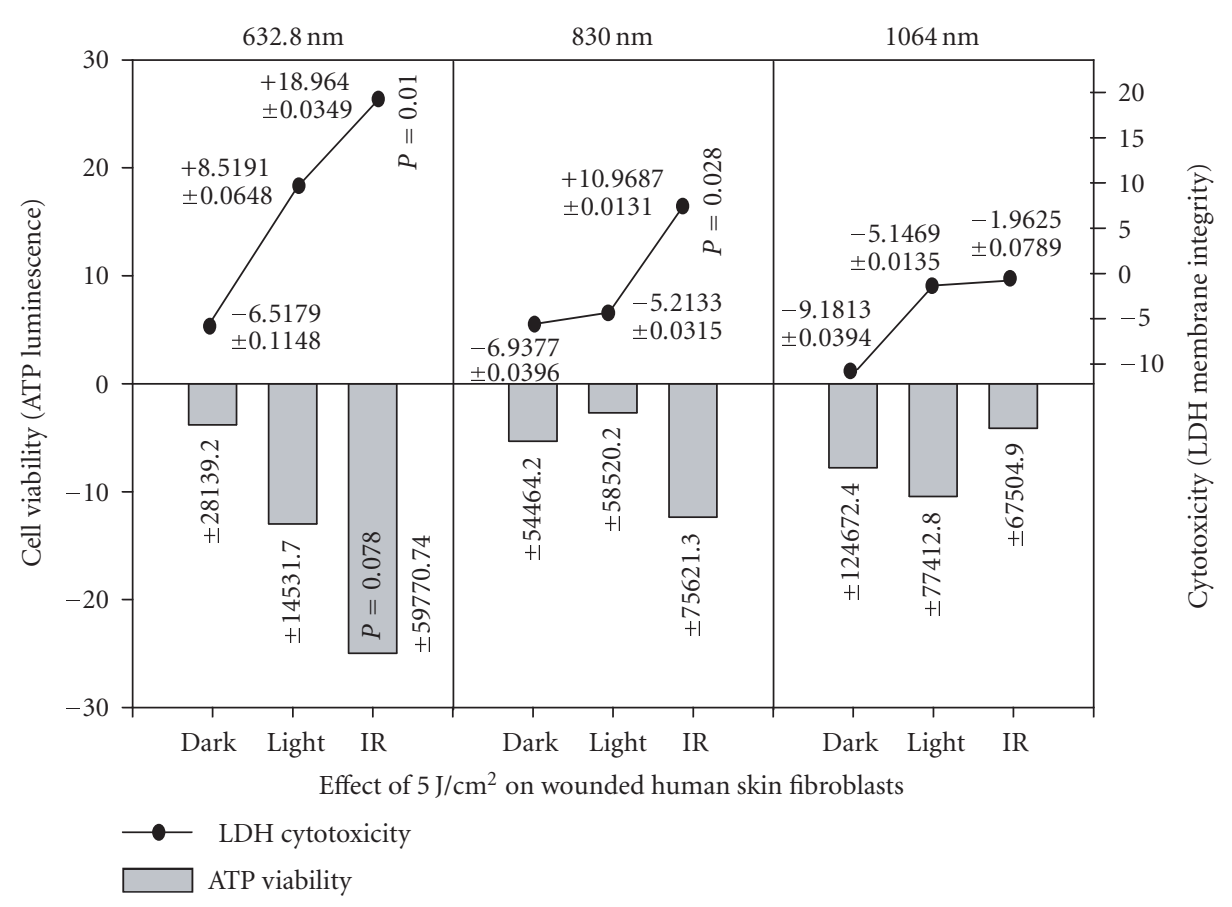

FIgURE 2: The ATP luminescence assay and LDH cytotoxicity assay were used to determine changes in cell viability for wounded cells exposed to $5 \mathrm{~J} / \mathrm{cm}^{2}$ using $632.8 \mathrm{~nm}, 830 \mathrm{~nm}$, or $1064 \mathrm{~nm}$ in light, dark, or IR. Wounded cells exposed to $5 \mathrm{~J} / \mathrm{cm}^{2}$ using $632.8 \mathrm{~nm}$ in IR showed a decrease in cell viability when compared to the unirradiated control $(P=0.078)$ indicating an increase in culture temperature since the cells were irradiated for 41 minutes and 40 seconds which ultimately caused thermal damage. The results also showed statistical differences between the different wavelengths indicating that the dose and wavelength are important parameters that influence the cellular responses. Wounded cells exposed to $5 \mathrm{~J} / \mathrm{cm}^{2}$ using $632.8 \mathrm{~nm}(P=0.010)$ or $830 \mathrm{~nm}(P=0.028)$ in IR showed an increase in cell LDH cytotoxicity when compared to the unirradiated control $(n=4)$.

however there is a difference between wounded cells exposed to $5 \mathrm{~J} / \mathrm{cm}^{2}$ using $1064 \mathrm{~nm}$ and $830 \mathrm{~nm}$ in the light $(P=0.013)$. Results show that there was no statistical difference between wounded cells irradiated with $5 \mathrm{~J} / \mathrm{cm}^{2}$ using $632.8 \mathrm{~nm}$ or $830 \mathrm{~nm}$ in the dark or the light, however wounded cells exposed to $5 \mathrm{~J} / \mathrm{cm}^{2}$ using $1064 \mathrm{~nm}$ in the dark show an increase in the cytotoxicity when compared to cells irradiated in the light $(P=0.0004)$.

\section{Apoptosis}

The caspase 3/7 luminescent assay was used to identify if the irradiation caused additional stress which may induce higher levels of apoptosis (Figure 3 ). Wounded cells exposed to $5 \mathrm{~J} / \mathrm{cm}^{2}$ using $632.8 \mathrm{~nm}$ in IR showed an increase in caspase $3 / 7$ activity when compared to the wounded unirradiated control $(P=0.364)$ and when compared to wounded cells exposed to $5 \mathrm{~J} / \mathrm{cm}^{2}$ using $632.8 \mathrm{~nm}$ in the dark $(P=0.0007)$ or in the light $(P=0.00003)$ indicating additional stress caused by IR light. Wounded cells exposed to $5 \mathrm{~J} / \mathrm{cm}^{2}$ using $632.8 \mathrm{~nm}$ in light showed decrease in caspase $3 / 7$ activity when compared to the wounded un-irradiated control $(P=0.433)$ and when compared to cells exposed to $5 \mathrm{~J} / \mathrm{cm}^{2}$ using $632.8 \mathrm{~nm}$ in the dark $(P=0.069)$.

Wounded cells exposed to $5 \mathrm{~J} / \mathrm{cm}^{2}$ using $830 \mathrm{~nm}$ in IR showed an increase in caspase $3 / 7$ activity when compared to wounded cells exposed to $5 \mathrm{~J} / \mathrm{cm}^{2}$ using $830 \mathrm{~nm}$ in the dark $(P=0.084)$ or in the light $(P=0.052)$ indicating additional stress caused by IR light. Wounded cells exposed to $5 \mathrm{~J} / \mathrm{cm}^{2}$ using $830 \mathrm{~nm}$ in light showed decrease in caspase $3 / 7$ activity when compared to the wounded unirradiated control $(P=0.880)$ and when compared to wounded cells exposed to $5 \mathrm{~J} / \mathrm{cm}^{2}$ using $632.8 \mathrm{~nm}$ in the dark $(P=0.931)$. Wounded cells exposed to $5 \mathrm{~J} / \mathrm{cm}^{2}$ using $1064 \mathrm{~nm}$ in IR showed a decrease in caspase $3 / 7$ activity when compared to the wounded unirradiated control $(P=0.852)$ and when compared to wounded cells exposed to $5 \mathrm{~J} / \mathrm{cm}^{2}$ using $1064 \mathrm{~nm}$ in the dark $(P=0.979)$ or in the light $(P=0.406)$ indicating a limited change in cell stress that may be related to the duration (6 minutes and 30 seconds) of the exposure to laser light and IR. Wounded cells exposed to $5 \mathrm{~J} / \mathrm{cm}^{2}$ using $1064 \mathrm{~nm}$ in the light showed an increase in caspase $3 / 7$ activity when compared to wounded cells exposed to $5 \mathrm{~J} / \mathrm{cm}^{2}$ using $632.8 \mathrm{~nm}$ in the light $(P=0.0179)$ indicating that the wavelength and treatment condition (in the light) may influence the biological response of the cells.

Wounded cells exposed to $5 \mathrm{~J} / \mathrm{cm}^{2}$ using $830 \mathrm{~nm}$ in IR showed an increase in caspase $3 / 7$ activity when compared to wounded cells exposed to $5 \mathrm{~J} / \mathrm{cm}^{2}$ using $1064 \mathrm{~nm}$ in IR $(P=$ 0.0038 ). Wounded cells exposed to $5 \mathrm{~J} / \mathrm{cm}^{2}$ using $1064 \mathrm{~nm}$ in IR showed a decrease in caspase $3 / 7$ activity when compared to wounded cells exposed to $5 \mathrm{~J} / \mathrm{cm}^{2}$ using $632.8 \mathrm{~nm}$ in IR 


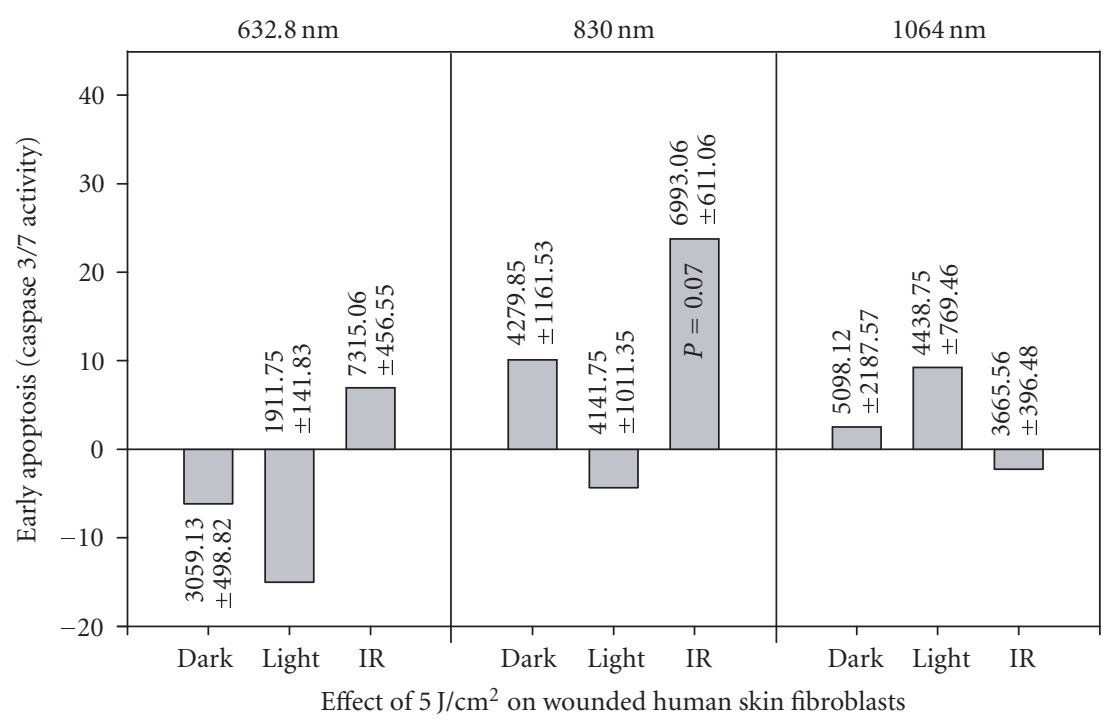

FIGURE 3: Early apoptosis in irradiated wounded fibroblasts exposed to $5 \mathrm{~J} / \mathrm{cm}^{2}$ using $632.8 \mathrm{~nm}, 830 \mathrm{~nm}$, or $1064 \mathrm{~nm}$ in light, dark, or IR was detected using caspase $3 / 7$ luminescence. Wounded cells exposed to $5 \mathrm{~J} / \mathrm{cm}^{2}$ using $830 \mathrm{~nm}$ in IR showed an increase in caspase $3 / 7$ activity when compared to the wounded unirradiated control $(P=0.070)$ indicating an undesirable thermal effect of IR light. Wounded cells exposed to $5 \mathrm{~J} / \mathrm{cm}^{2}$ using $632.8 \mathrm{~nm}$ in the dark or light, $830 \mathrm{~nm}$ in the dark, and $1064 \mathrm{~nm}$ in IR showed a decrease in caspase $3 / 7$ activity which indicates a decrease in cells stress or damage. Results show that there are statistical variations between wounded cells exposed to $632.8 \mathrm{~nm}, 830 \mathrm{~nm}$, or $1064 \mathrm{~nm}$ in the light or in IR indicating that the dose, treatment condition, and wavelength influence the average response of the cells $(n=4)$.

$(P=0.001)$, however there was no change in activity between wounded cells exposed to $5 \mathrm{~J} / \mathrm{cm}^{2}$ using $830 \mathrm{~nm}$ in IR and wounded cells exposed to $5 \mathrm{~J} / \mathrm{cm}^{2}$ using $632.8 \mathrm{~nm}$ in IR $(P=0.687)$.

\section{DISCUSSION}

Karu [27] stated that the laser effect depends on the radiation wavelength, dose, and intensity, as well as on the cell culture conditions [27]. There are biological limits to the effects of LLLT: the proliferation of fast-growing cells cannot be stimulated, or not all cellular functions can be activated. Not all cells in tissues or cellular cultures will respond to irradiation in exactly the same way. The total response from the cells may represent the average rather than the true value, which has little meaning in the clinic but is important in a cell study. Many experiments have been performed in vitro and the reaction seen or not seen in an in vitro experiment reflects the effect of laser therapy on a single isolated cell [28]. In the clinic, there is no single-cell effect, instead a very complex and multipath cascade of processes that influences every cell in the body at each particular moment.

Karu et al. [5] has shown that the effect of laser light may be partly or completely reduced by broad-spectrum light [5]. When wounded or scratched, cell monolayers respond to the disruption of cell-cell contacts with an increased concentration of growth factors at the wound margin and by healing the wound through a combination of proliferation and migration [29-31]. These processes reflect the behavior of in- dividual cells as well as the properties of the cell sheet as a surrogate tissue.

The ATP cell viability results show that wounded cells exposed to $5 \mathrm{~J} / \mathrm{cm}^{2}$ using $632.8 \mathrm{~nm}$ in IR showed a decrease in ATP viability indicating an increase in cellular damage possibly caused by an increase in culture temperature since the cells were irradiated for a longer period of 41 minutes and 40 seconds when compared to $830 \mathrm{~nm}$ (12 minutes and 45 seconds) and $1064 \mathrm{~nm}$ ( 6 minutes and 30 seconds). Wounded cells exposed to $5 \mathrm{~J} / \mathrm{cm}^{2}$ using $830 \mathrm{~nm}$ in IR showed a decrease in ATP viability supporting the evidence that IR may cause thermal damage or unwanted thermal influences during LLLT. Wounded cells exposed to $5 \mathrm{~J} / \mathrm{cm}^{2}$ using $1064 \mathrm{~nm}$ in the light and dark showed a decrease in ATP viability when compared to cells irradiated in IR indicating that the IR light may support the $1064 \mathrm{~nm}$ nearinfrared laser light or that the cells are incubated for a minimal period of 6 minutes and 30 seconds limiting any undesirable thermal effects. Results show that there was a statistical difference between wounded cells exposed to $5 \mathrm{~J} / \mathrm{cm}^{2}$ using $632.8 \mathrm{~nm}, 830 \mathrm{~nm}$, and $1064 \mathrm{~nm}$ in the light indicating that the cellular response is dependent on the wavelength. The similar response was demonstrated for wounded cells exposed to $5 \mathrm{~J} / \mathrm{cm}^{2}$ in the dark and IR supporting the evidence that the dose, wavelength, and treatment conditions are important parameters that influence the biological responses of irradiated cells. The ATP results show that wounded cells exposed to $5 \mathrm{~J} / \mathrm{cm}^{2}$ using $830 \mathrm{~nm}$ and $1064 \mathrm{~nm}$ in the light are not statistically different from cells exposed in 
the dark, therefore it appears that the response is influenced by a change in temperature, dose, and wavelength.

The LDH cytotoxicity showed that wounded cells had an increase in membrane damage after they were exposed to $5 \mathrm{~J} / \mathrm{cm}^{2}$ using $632.8 \mathrm{~nm}$ and $830 \mathrm{~nm}$ in IR. The results correspond to the decrease in ATP cell viability that was observed indicating that IR causes thermal damage. The results show that wounded cells exposed to $5 \mathrm{~J} / \mathrm{cm}^{2}$ using $1064 \mathrm{~nm}$ in IR did not result in a significant change in the cytotoxicity when compared to wounded cells exposed to $5 \mathrm{~J} / \mathrm{cm}^{2}$ in the light. This result corresponds to an increase in the ATP viability for $5 \mathrm{~J} / \mathrm{cm}^{2}$ using $1064 \mathrm{~nm}$ in IR indicating that IR light may support and assist laser irradiation provided the duration of the irradiation is short since longer durations appear to cause undesirable thermal damage. The $\mathrm{LDH}$ results show that wounded cells exposed to $5 \mathrm{~J} / \mathrm{cm}^{2}$ using $632.8 \mathrm{~nm}$ and $830 \mathrm{~nm}$ in the light are not statistically different from cells exposed in the dark, however there is a difference between cells exposed to $5 \mathrm{~J} / \mathrm{cm}^{2}$ using $1064 \mathrm{~nm}$ in the light or dark supporting the evidence that ambient or broad-spectrum light reduces the biological effect and indicates that there are more mechanisms at work than simply the excitation of polarization-sensitive chromophores [5].

Results show that wounded cells exposed to $5 \mathrm{~J} / \mathrm{cm}^{2}$ using $632.8 \mathrm{~nm}$ in the light or IR have an increase in cytotoxicity when compared to wounded cells exposed to $5 \mathrm{~J} / \mathrm{cm}^{2}$ using $830 \mathrm{~nm}$ in the light or IR supporting the evidence that the wavelength is an important parameter that can influence the cellular response to laser irradiation. Wounded cells exposed to $5 \mathrm{~J} / \mathrm{cm}^{2}$ using $1064 \mathrm{~nm}$ in the dark or light show a difference in LDH cytotoxicity when compared to wounded cells exposed to $5 \mathrm{~J} / \mathrm{cm}^{2}$ using $830 \mathrm{~nm}$ in the dark or light supporting the evidence that the response depends on the wavelength. Results show that wounded cells exposed to $5 \mathrm{~J} / \mathrm{cm}^{2}$ using $632.8 \mathrm{~nm}$ and $830 \mathrm{~nm}$ in IR have an increase in cytotoxicity when compared to wounded cells exposed to $5 \mathrm{~J} / \mathrm{cm}^{2}$ using $1064 \mathrm{~nm}$ in IR suggesting that the increase in irradiation time of 41 minutes and 40 seconds for $632.8 \mathrm{~nm}$ and 12 minutes and 45 seconds for $830 \mathrm{~nm}$ compared to 6 minutes and 30 seconds for $1064 \mathrm{~nm}$ may result in thermal damage or unwanted thermal influences from the IR light. Wounded cells exposed to $5 \mathrm{~J} / \mathrm{cm}^{2}$ using $1064 \mathrm{~nm}$ in IR showed a similar biological response to wounded cells exposed to $5 \mathrm{~J} / \mathrm{cm}^{2}$ using $632.8 \mathrm{~nm}$ in the dark, however there was an increase in LDH cytotoxicity for $1064 \mathrm{~nm}$ which may indicate more damage to the cells. Wounded cells exposed to $5 \mathrm{~J} / \mathrm{cm}^{2}$ using $830 \mathrm{~nm}$ in light showed a similar biological response to wounded cells exposed to $5 \mathrm{~J} / \mathrm{cm}^{2}$ using $632.8 \mathrm{~nm}$ in the dark indicating an alternative wavelength and treatment condition that results in a similar response.

Wounded cells exposed to $5 \mathrm{~J} / \mathrm{cm}^{2}$ using $632.8 \mathrm{~nm}$ or $830 \mathrm{~nm}$ in the light showed a decrease in caspase 3/7 activity which did not correspond with the LDH cytotoxicity results. Wounded cells exposed to $5 \mathrm{~J} / \mathrm{cm}^{2}$ using $1064 \mathrm{~nm}$ in the light showed an increase in caspase $3 / 7$ activity that corresponds to the ATP viability and LDH cytotoxicity. These results indicate that ambient or broad-spectrum light changes the biological response of wounded cells to laser irradia- tion. The caspase $3 / 7$ activity increased for wounded cells that were exposed to $5 \mathrm{~J} / \mathrm{cm}^{2}$ using $632.8 \mathrm{~nm}$ (41 minutes and 40 seconds) or $830 \mathrm{~nm}$ ( 12 minutes and 45 seconds) in IR light when compared to the activity for $1064 \mathrm{~nm}$ ( 6 minutes and 30 seconds). The results suggest that IR light in combination with laser irradiation may only be of benefit if the duration of the exposure is minimal. The results indicate that the undesirable thermal effect of IR light is dependent on and directly proportional to the duration or length of exposure.

The results indicate that wounded cells exposed to $5 \mathrm{~J} / \mathrm{cm}^{2}$ using $1064 \mathrm{~nm}$ do not show statistical variations in cell stress when irradiated in the dark, in the light, or in IR, however there are statistical variations in ATP viability and LDH cytotoxicity. The results show that there are statistical variations between the different wavelengths when wounded cells are exposed to $5 \mathrm{~J} / \mathrm{cm}^{2}$ using $632.8 \mathrm{~nm}, 830 \mathrm{~nm}$, and $1064 \mathrm{~nm}$ in the light and IR, however there are no statistical variations between the different wavelengths when wounded cells are exposed in the dark. The result suggests that the wavelength and treatment conditions are important parameters that influence the biological response. The results also support the evidence that broad-spectrum light changes the biological response [5]. Karu and Kolyakov [32] reported that the wavelength range important for phototherapy (600-860 nm) has four active regions, but peak positions are not exactly the same for all spectra. The peak positions are between 613.5 and $623.5 \mathrm{~nm}$ in the red maximum and two near-infrared maxima have peak positions in the range $750.7-772.3 \mathrm{~nm}$ and $812.5-846 \mathrm{~nm}$, respectively [32]. This may explain why broad-spectrum light changes the biological response since it may influence the peak active region of each wavelength.

The results using the ATP viability, LDH cytotoxicity, and caspase $3 / 7$ activity show the following: $5 \mathrm{~J} / \mathrm{cm}^{2}$ using $632.8 \mathrm{~nm}$ in the dark is more effective than $830 \mathrm{~nm}$ in the dark; $632.8 \mathrm{~nm}$ in the dark is more effective than $1064 \mathrm{~nm}$ in the dark, and $1064 \mathrm{~nm}$ in the dark is more effective than $830 \mathrm{~nm}$. Results also show that $5 \mathrm{~J} / \mathrm{cm}^{2}$ using $830 \mathrm{~nm}$ in the light is more effective than $632.8 \mathrm{~nm}$ in the light but not as effective as $632.8 \mathrm{~nm}$ in the dark; $632.8 \mathrm{~nm}$ in the light is more effective than $1064 \mathrm{~nm}$ in the light but not as effective as $632.8 \mathrm{~nm}$ in the dark, and exposure to $830 \mathrm{~nm}$ in the light is more effective than $1064 \mathrm{~nm}$ in the light. Therefore the results indicate that $632.8 \mathrm{~nm}$ in the dark is the most effective.

\section{CONCLUSION}

Wounded cells respond with an increase in ATP viability and a decrease in LDH cytotoxicity when exposed to $5 \mathrm{~J} / \mathrm{cm}^{2}$ using $632.8 \mathrm{~nm}$ in the dark or $830 \mathrm{~nm}$ in the light. Results showed that only the increase in LDH cytotoxicity differentiated wounded cells exposed to $5 \mathrm{~J} / \mathrm{cm}^{2}$ using $1064 \mathrm{~nm}$ in IR from cells exposed to $1064 \mathrm{~nm}$ in the dark indicating that IR light can support laser irradiation with $1064 \mathrm{~nm}$ provided that the duration of exposure is minimal to limit the undesirable thermal effects.

Wounded cells exposed to $5 \mathrm{~J} / \mathrm{cm}^{2}$ using $632.8 \mathrm{~nm}$ in the light result in a decrease in caspase $3 / 7$ activity when 
compared to cells exposed in the dark. The results support findings from Hawkins and Abrahamse [33], which reported that $5 \mathrm{~J} / \mathrm{cm}^{2}$ using $632.8 \mathrm{~nm}$ stimulates mitochondrial activity, cell proliferation, and migration to accelerate wound closure [33]. However, wounded cells exposed to $5 \mathrm{~J} / \mathrm{cm}^{2}$ using $632.8 \mathrm{~nm}$ in IR show an increase in caspase $3 / 7$, increase in cytotoxicity, and decrease in viability when compared to cells exposed in the dark or in the light indicating an undesirable thermal effect of IR light. Wounded cells respond to $5 \mathrm{~J} / \mathrm{cm}^{2}$ using $632.8 \mathrm{~nm}$ or $830 \mathrm{~nm}$ in IR with an increase in LDH cytotoxicity and caspase $3 / 7$ activity but with a decrease in ATP viability and decrease in cell proliferation indicating an undesirable thermal effect of IR light that may inhibit other biological responses such as the expression of growth factors such as basic fibroblast growth factor (bFGF). The results show that wounded cells exposed to $5 \mathrm{~J} / \mathrm{cm}^{2}$ using $632.8 \mathrm{~nm}$ or $1064 \mathrm{~nm}$ in the dark respond with a decrease in LDH cytotoxicity and increase in ATP viability when compared to cells exposed in the light indicating that broad-spectrum light decreases the biological response of cells to laser light. Wounded cells exposed to $5 \mathrm{~J} / \mathrm{cm}^{2}$ using $632.8 \mathrm{~nm}$ in IR show a statistical decrease in ATP viability demonstrating that IR light has a detrimental effect and does not assist phototherapy. Results show that the effect of IR light with $830 \mathrm{~nm}$ or $1064 \mathrm{~nm}$ laser light is dependent on the duration of the exposure.

Results from the study may be useful in defining laser parameters for clinical applications where clinicians may be able to use broad-spectrum or IR light in combination with phototherapy to improve the laser effect for specific applications. This in vitro study has shown that the effect of IR light is determined by the duration of the laser irradiation as may only be beneficial in combination with short laser exposures to avoid an undesirable thermal effect. It should be noted that this study concentrates on the effect of IR and broad-spectrum light in combination with phototherapy on cell culture and that the effect in an animal or human wound model may be different and may be dependent on other contributing factors such as blood flow, cytokine expression, inflammatory response, and endorphins (pain relief) to minimize the undesirable thermal effect. With further research, the use of IR light in combination with phototherapy may be useful in clinical applications such as pain relief and musculoskeletal injuries. The results support published findings by Enwemeka et al. [26] that revealed the positive effects of various wavelengths of laser light on tissue repair, with $632.8 \mathrm{~nm}$ having the highest treatment effect and $780 \mathrm{~nm}$ the least and concluded that phototherapy is a highly effective therapeutic armamentarium for tissue repair and pain relief [26].

To conclude, the results show that wounded cells responded optimally to $5 \mathrm{~J} / \mathrm{cm}^{2}$ using $632.8 \mathrm{~nm}$ in the dark, $830 \mathrm{~nm}$ in the light, and $1064 \mathrm{~nm}$ in the dark by maintaining cell viability, reducing cytotoxicity, stimulating the release of cytokines and growth factors to ultimately stimulate cell proliferation and cell growth. The results indicate that the exposures identified stimulate the metabolic activity of wounded cells, which may ultimately accelerate or improve the rate of wound healing.

\section{ACKNOWLEDGMENTS}

This project is jointly funded by the University of Johannesburg, National Laser Centre (NLC), National Research Foundation (NRF), and Medical Research Council (MRC).

\section{REFERENCES}

[1] B. Shaffer, "Scientific basis of laser energy," Clinics in Sports Medicine, vol. 21, no. 4, pp. 585-598, 2002.

[2] N. Bhatta, K. Isaacson, K. M. Bhatta, R. R. Anderson, and I. Schiff, "Comparative study of different laser systems," Fertility and Sterility, vol. 61, no. 4, pp. 581-591, 1994.

[3] J. P. Garino, P. A. Lotke, A. A. Sapega, P. J. Reilly, and J. L. Esterhai Jr., "Osteonecrosis of the knee following laser-assisted arthroscopic surgery: a report of six cases," Arthroscopy, vol. 11, no. 4, pp. 467-474, 1995.

[4] S. J. Gitomer and R. D. Jones, "Laser-produced plasmas in medicine," in Laser-Tissue Interaction, S. L. Jacques, Ed., vol. 1202 of Proceedings of SPIE, pp. 118-132, Los Angeles, Calif, USA, January 1990.

[5] T. I. Karu, G. S. Kalendo, V. S. Letokhov, and V. V. Lobko, "Biostimulation fo Hela cells by low-intensity visible light," Il Nuovo Cimento D, vol. 1, no. 6, pp. 828-840, 1982.

[6] I. Stadler, R. J. Lanzafame, P. Oskoui, R.-Y. Zhang, J. Coleman, and M. Whittaker, "Alteration of skin temperature during low-level laser irradiation at $830 \mathrm{~nm}$ in a mouse model," Photomedicine and Laser Surgery, vol. 22, no. 3, pp. 227-231, 2004.

[7] I. Greppi, "Diode laser hair removal of the black patient," Lasers in Surgery and Medicine, vol. 28, no. 2, pp. 150-155, 2001.

[8] O. N. Bogacheva, K. A. Samoilova, N. A. Zhevago, et al., "Enhancement of fibroblast growth promoting activity of human blood after its irradiation in vivo (transcutaneously) and in vitro with visible and infrared polarized light," Tsitologiia, vol. 46, no. 2, pp. 159-171, 2004.

[9] J. Kubota, "Defocused diode laser therapy $(830 \mathrm{~nm})$ in the treatment of unresponsive skin ulcers: a preliminary trial," Journal of Cosmetic and Laser Therapy, vol. 6, no. 2, pp. 96102, 2004.

[10] H. Meffert, H. P. Scherf, H. Bäumler, et al., "Systemic effects of ultraviolet, visible and infrared radiation in serial whole body irradiation. I. Oxygen utilization, flow properties of blood, hemodynamics, blood components and phagocytosis," Dermatologische Monatsschrift, vol. 175, no. 10, pp. 609-622, 1989.

[11] S. Belotsky, R. Avtalion, M. Sinyakov, R. Lavi, and R. Lubart, "Visible light affects chemiluminescence of carp (Cyprinus carpio) blood leukocytes," Photomedicine and Laser Surgery, vol. 22, no. 3, pp. 255-258, 2004.

[12] R. J. Lanzafame, I. Stadler, J. Coleman, et al., "Temperaturecontrolled 830-nm low-level laser therapy of experimental pressure ulcers," Photomedicine and Laser Surgery, vol. 22, no. 6, pp. 483-488, 2004.

[13] Y. Maegawa, T. Itoh, T. Hosokawa, K. Yaegashi, and M. Nishi, "Effects of near-infrared low-level laser irradiation on microcirculation," Lasers in Surgery and Medicine, vol. 27, no. 5, pp. 427-437, 2000.

[14] R. Ausubel, R. Brent, R. E. Kingston, et al., Short Protocols in Molecular Cloning, John Wiley \& Sons, New York, NY, USA, 4th edition, 1994. 
[15] J. Sambrook, E. F. Fritsch, and T. Maniatis, Molecular Cloning: A laboratory Manual, Cold Spring Harbor Laboratory Press, New York, NY, USA, 2nd edition, 1989.

[16] M. Kreisler, A. B. Christoffers, B. Willershausen, and B. D'Hoedt, "Low-level $809 \mathrm{~nm}$ GaAIAs laser irradiation increases the proliferation rate of human laryngeal carcinoma cells in vitro," Lasers in Medical Science, vol. 18, no. 2, pp. 100103, 2003.

[17] J. C. Yarrow, Z. E. Perlman, N. J. Westwood, and T. J. Mitchison, "A high-throughput cell migration assay using scratch wound healing, a comparison of image-based readout methods," BMC Biotechnology, vol. 4, no. 1, p. 21, 2004.

[18] W. Posten, D. A. Wrone, J. S. Dover, K. A. Arndt, S. Silapunt, and M. Alam, "Low-level laser therapy for wound healing: mechanism and efficacy," Dermatologic Surgery, vol. 31, no. 3, pp. 334-340, 2005.

[19] D. Cha, P. O'Brien, E. A. O'Toole, D. T. Woodley, and L. G. Hudson, "Enhanced modulation of keratinocyte motility by transforming growth factor- $\alpha$ (TGF- $\alpha$ ) relative to epidermal growth factor (EGF)," Journal of Investigative Dermatology, vol. 106, no. 4, pp. 590-597, 1996.

[20] D. G. Siposan and A. Lukacs, "Relative variation to received dose of some erythrocytic and leukocytic indices of human blood as a result of low-level laser radiation: an in vitro study," Journal of Clinical Laser Medicine and Surgery, vol. 19, no. 2, pp. 89-103, 2001.

[21] J. Rigau, C.-H. Sun, M. A. Trelles, and M. W. Berns, "Effects of the 633-nm laser on the behavior and morphology of primary fibroblast culture," in Effects of Low-Power Light on Biological Systems, T. I. Karu and A. R. Young, Eds., vol. 2630 of Proceedings of SPIE, pp. 38-42, Barcelona, Spain, September 1996.

[22] T. Riss, R. Moravec, M. Beck, R. Hannah, K. Wilson, and R. Swanson, "CellTiter-Glo ${ }^{\mathrm{TM}}$ luminescent cell viability assay: fast, sensitive and flexible," Promega Notes Magazine, vol. 81, pp. 2-5, 2002.

[23] S. P. M. Crouch, R. Kozlowski, K. J. Slater, and J. Fletcher, "The use of ATP bioluminescence as a measure of cell proliferation and cytotoxicity," Journal of Immunological Methods, vol. 160, no. 1, pp. 81-88, 1993.

[24] R. Moravec, "Total cell quantitation using the CytoTox $96^{\mathrm{TM}}$ non-radioactive cytotoxicity assay," Promega Notes, vol. 45, pp. 11-12, 1994.

[25] D. W. Nicholson and N. A. Thornberry, "Caspases: killer proteases," Trends in Biochemical Sciences, vol. 22, no. 8, pp. 299306, 1997.

[26] C. S. Enwemeka, J. C. Parker, D. S. Dowdy, E. E. Harkness, L. E. Sanford, and L. D. Woodruff, "The efficacy of low-power lasers in tissue repair and pain control: a meta-analysis study," Photomedicine and Laser Surgery, vol. 22, no. 4, pp. 323-329, 2004.

[27] T. Karu, "Primary and secondary mechanisms of the action of monochromatic visible and near infrared radiation on cells," in The Science of Low-Power Laser Therapy, p. 33, Gordon and Breach Science, Amsterdam, The Netherlands, 1998.

[28] J. Tunér and L. Hode, Laser Therapy-Clinical Practice and Scientific Background, Prima Books AB, Grängesberg, Sweden, 2002.

[29] M. K. Wong and A. I. Gotlieb, "The reorganization of microfilaments, centrosomes, and microtubules during in vitro small wound reendothelialization," Journal of Cell Biology, vol. 107, no. 5, pp. 1777-1783, 1988 .
[30] B. L. Coomber and A. I. Gotlieb, "In vitro endothelial wound repair. Interaction of cell migration and proliferation," Arteriosclerosis, vol. 10, no. 2, pp. 215-222, 1990.

[31] J.-M. Zahm, H. Kaplan, A.-L. Hérard, et al., "Cell migration and proliferation during the in vitro wound repair of the respiratory epithelium," Cell Motility and the Cytoskeleton, vol. 37, no. 1, pp. 33-43, 1997.

[32] T. I. Karu and S. F. Kolyakov, "Exact action spectra for cellular responses relevant to phototherapy," Photomedicine and Laser Surgery, vol. 23, no. 4, pp. 355-361, 2005.

[33] D. Hawkins and H. Abrahamse, "Biological effects of HeliumNeon laser irradiation on normal and wounded human skin fibroblasts," Photomedicine and Laser Surgery, vol. 23, no. 3, pp. 251-259, 2005. 